\title{
Blended Humor and Mind Mapping in Improving 21st Century Skills
}

\author{
Anastasia Dewi Anggraeni* \\ Universitas Indraprasta PGRI, Jl. Nangka Raya No.58 C, Jakarta Selatan, 12530 \\ anastasia,dewi@unindra.ac.id \\ *corresponding author
}

\begin{tabular}{|c|c|}
\hline ARTICLE INFO & ABSTRACT \\
\hline \multirow[t]{3}{*}{$\begin{array}{l}\text { Article history } \\
\text { Received January 2, } 2019 \\
\text { Revised February 7, } 2019 \\
\text { Accepted April 27, } 2019\end{array}$} & 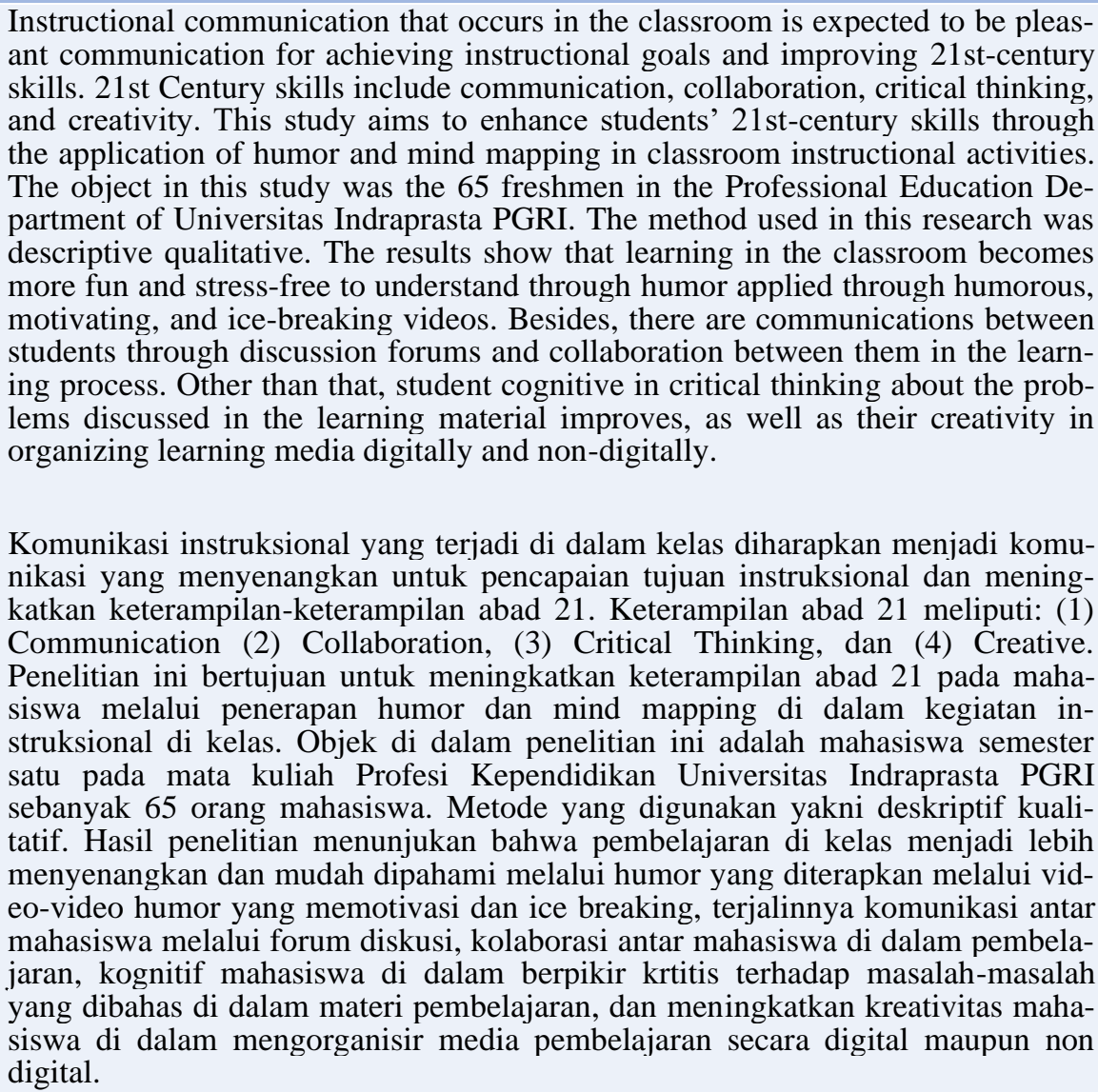 \\
\hline & This is an open access article under the $\mathrm{CC}-\mathrm{BY}$ license. \\
\hline & (c) \\
\hline
\end{tabular}

\section{Introduction}

In the 21st century, Indonesia's young generations face various complex internal, as well as external problems that require exceptional skill and competence. Thus, the Indonesian education system should anticipate those problems through educational actions that produce reliable outcomes in facing 21 stcentury living.
Therefore, communication, collaboration, critical thinking, and creativity skills (4C) should be advanced. The advancement of those four skills is essential to realize the high competitiveness of the 2045 Golden Generation (Muhlisin \& Kunci, 2017).

In the effort to develop those four skills, teachers, as educators, need to recognize eve- 
ry student's competence. Consequently, teachers must understand self-assessment. Warner (Adnyana \& PF, 2019) states that during the critical thinking phase, teachers have to evaluate the students' fundamental thinking level. In other words, teachers must assess if the students can think fundamentally, critically, and logically. Additionally, in the collaboration phase, they must know students' ability to collaborate with their peers in teamwork. In this phase, students are expected to establish social networks for their future careers. In the communication phase, teachers must understand students' ability to filter the information they gain through social media. This ability is critical due to the hoaxes that may disturb communication among students and their environment. The last, in the creativity phase, teachers must measure students' creativity in developing their competencies and skills using online media.

Currently, education should emphasize the high order thinking skills in facing the recent competitive learning process challenges. Teachers should no longer focus on lecturing or giving assignments in their learning. Educators, primarily lecturers, should better stimulate the students and create fun learning to accelerate students' 21 st skills.

Teachers' performance and competencies carry the most significant responsibilities to reconstruct ignorance into awareness, dependency into independence, uncreative into creative, by various learning methods. That effort aims to generate knowledgeable learners capable of adapting and understanding new information through thinking, questioning, investigating, creating, and developing processes to solve their life problems.

Teachers play a critical role in learning as they become the primary mediator for the students' success. The learning process affectivity emphasizes on the learning outcomes. That affectivity is affected by the learning approaches and methods used by teachers (Anggraeni, 2018).

In the Education Profession course, which is one of the compulsory courses for the English Education department's students of Universitas Indraprasta PGRI; students are introduced to several fields of educational career. Students are expected to master the skills to be qualified teachers, as well as the educational problems, face by teachers.
Therefore, the lecturer in this course has to implement creative and innovative learning. Creative teachers can use various teaching methods by their materials or themes (Anggraeni, 2018). There are different teaching methods; one of them is the mind mapping method.

According to Swadarma (Khsaniatun et al., 2014), mind mapping is an operative, attractive, effortless, and practical way to take notes by mapping our minds. Besides, Martin (Khsaniatun et al., 2014) mentions that mind mapping is the new essential innovation that provokes students to create meaningful learning in the classroom. It is equipped with concrete visual that helps students to organize information before they learn it.

In addition, according to Buzan (Astuti, T, 2019), mind mapping is a technique that uses every part of our brain through visual image and graphic infrastructure to create an impression. A research conducted by Made et al. (Mariyan et al., 2013) shows that mind mapping improves the creative thinking skill of tenth grader students' in Darul Ulum Agung High school Malang. Other than that, creative thinking is also perceived as one of the processes of conceiving a new idea.

That idea is also supported by research conducted by Raswel and Firman (Setyarini, 2019) that found three things. There are different social science learning results and creativity between students' who use mind mapping learning, and those who use conventional learning. Besides, they also find a significant positive contribution among the creativity and learning results of sixth-grader elementary school students in social science subjects.

Other than the implementation of mind mapping within the learning process, the use of humor also attracts college students' attention. It provokes college students' attention and readiness. In Indonesia, humor is famous as a feeling or symptom that mentally stimulates us to laugh. It can be a feeling or sense of humor, as well as a symptom or outcome from internal or external parts of our body (Musyafa, M, 2017).

O'Connell (Musyafa, M, 2017) states that a sense of humor is the ability to precisely change the cognitive-perceptual on the framework of thinking. It can adjust someone's perspective, to make something that is perceived to be negative into positive. 
In education, humor can produce fun learning. Stopsky (Musyafa, M, 2017)states that humor is the main component that forces students to think more critically. In agreement with that, Nilson (Musyafa, M, 2017), says that humor is one of the essential learning tools, due to its effectivity in attracting someone's attention to listen to the discussion, as well as, one of the reliable persuasive tools.

Humor can appear in the form of verbal, written, or picturized stories. The spoken story may take form in riddles, puzzles, satire, critics, and so forth, directly delivered to the audience (Musyafa, M, 2017).

Humor can also be applied in the learning media, as mentioned by (Anggraeni \& Pentury, 2018), there are various kinds of media, but visual aids are the appropriate media for learners, particularly young learners. The visual aids which commonly used for teaching English are pictures, really or real objects, drawings, or teacher-made drawings, charts, posters, cartoons, and flashcards (Anggraeni \& Pentury, 2018). Thus, it can also be administered in the Educational $\mathrm{Ca}$ reer course with some adjustments regarding the course.

Multimedia is commonly used as the learning media in various courses. The use of this learning media can be the alternative to answer students learning needs with different characteristics. As stated by Newby, Stepich, Lehman, \& Russell (Hidayah et al., 2018), multimedia is a combination of various media. In other words, multimedia is the integration of several types of media, along with different technologies, to improve the learning process.

Based on the problems and the literature review mentioned above, the issue in this research is what type of practical learning methods that produce exceptional instructional communication to accelerate students' 21st-century skills. Therefore, this research aims to create a fun learning for the Educational Career course to improve students' 21 st-century skills (communication, collaboration, critical thinking, and creativity) in this globalization era.

\section{Method}

This research is quasi-experiment research due to. The randomization process toward students who are grouped into particular clas- ses interrupts the existing class order (Mariyan et al., 2013). The research method used in this research was descriptive qualitative with a sample taken from two Educational Career classes for English Education Department students of Universitas Indraprasta PGRI academic year of 2018/2019.

This qualitative research acted as a human instrument to determine the research focus, the informant as the source of data, data quality evaluation, data analysis, data interpretation, and concluding process for the findings (Sugiyono, P, 2017). The informant for the qualitative method was continuously developed (snowball) with aims (purposive) until the saturated data was reached (redundancy). Consequently, the researcher is the critical instrument for collecting the data; thus, the researcher actively collected the data by herself (Gunawan, 2013). The tools utilized for the data collection in this research is an in-depth interview, observation, and documentation.

\section{Results and Discussion}

Based on the results of the learning process observation or investigation in the classroom. There were various activities done by students in the classroom. Since the semester credit hour for one Educational Career course is three or two and a half hours for every meeting, thus the implementation of mind mapping and humor in the classroom learning process was arranged as presented in Table 1.

The activity that was done by students usually started by watching motivational animation videos that had humor. The videos attracted students' attention to be ready for the learning process. The video that inspires or motivates students are widely available in Youtube.com.

Other activities done by the students were creating a video (vlog) based on the materials and creating a mind map. Creating the video (vlog) helps students to collaborate with their peers. The use of mind mapping in the learning process, enforces their creativity, as well as enables them to create new ideas during the brainstorming and discussion session. Besides, mind mapping also creates open communication in the brainstorming and discussion groups. All those activities were done to cultivate students' creativity. 
Table 1. Implementation of Humor and Mind Mapping in the Learning Process

\begin{tabular}{|c|c|c|c|}
\hline Materials & Media & Activities & Skills \\
\hline $\begin{array}{l}\text { Fundamental concept about } \\
\text { Educational Career }\end{array}$ & Animation video & $\begin{array}{l}\text { Watching the video, and } \\
\text { creating a mind-map }\end{array}$ & Creative thinking and creativity \\
\hline Teachers' Competences & $\begin{array}{l}\text { Motivational } \\
\text { animation video }\end{array}$ & $\begin{array}{l}\text { Watching the video, creating a } \\
\text { mind map, and having a } \\
\text { discussion }\end{array}$ & $\begin{array}{l}\text { Communication, collaboration, } \\
\text { critical thinking, creativity }\end{array}$ \\
\hline $\begin{array}{l}\text { Counselling Guidance } \\
\text { Teachers Career }\end{array}$ & $\begin{array}{l}\text { Video / short movie } \\
\text { with humor }\end{array}$ & $\begin{array}{l}\text { Creating a short movie and a } \\
\text { mind-map }\end{array}$ & $\begin{array}{l}\text { Communication, collaboration, } \\
\text { critical thinking, creativity }\end{array}$ \\
\hline $\begin{array}{l}\text { Educational Administration } \\
\text { in the Teacher Career }\end{array}$ & $\begin{array}{l}\text { Powerpoint and } \\
\text { Powtoon. }\end{array}$ & $\begin{array}{l}\text { Creating a mind map and } \\
\text { drama. }\end{array}$ & $\begin{array}{l}\text { Communication, collaboration, } \\
\text { critical thinking, creativity }\end{array}$ \\
\hline Educational Supervision & $\begin{array}{l}\text { Motivational } \\
\text { animation video }\end{array}$ & $\begin{array}{l}\text { Watching the video, creating a } \\
\text { mind map, and having a } \\
\text { discussion }\end{array}$ & $\begin{array}{l}\text { Communication, collaboration, } \\
\text { critical thinking, creativity }\end{array}$ \\
\hline $\begin{array}{l}\text { Issues of Teachers across } \\
\text { Indonesia }\end{array}$ & Vlog / video & Creating a mind-map and vlog & $\begin{array}{l}\text { Communication, collaboration, } \\
\text { critical thinking, creativity }\end{array}$ \\
\hline
\end{tabular}

Teachers act as facilitator, mediator, advisor, and evaluator in the learning process. At the end of every meeting, teachers always delivered the conclusion of the materials students had learned. Table 2 shows students' average scores for the mid-term and final tests. Fig. 1, shows the students' score improvement. Thus, the use of mind-mapping and humor as the learning method contributes to the students' evaluation results.

Table 2. Students Average Scores on the MidTerm and Final Tests

\begin{tabular}{ccc}
\hline Class & $\begin{array}{c}\text { Mid-term Test } \\
\text { Average Score }\end{array}$ & $\begin{array}{c}\text { Final Test } \\
\text { Average Score }\end{array}$ \\
\hline R1E & 89,45 & 91,30 \\
\hline R1F & 87,88 & 92,27 \\
\hline
\end{tabular}

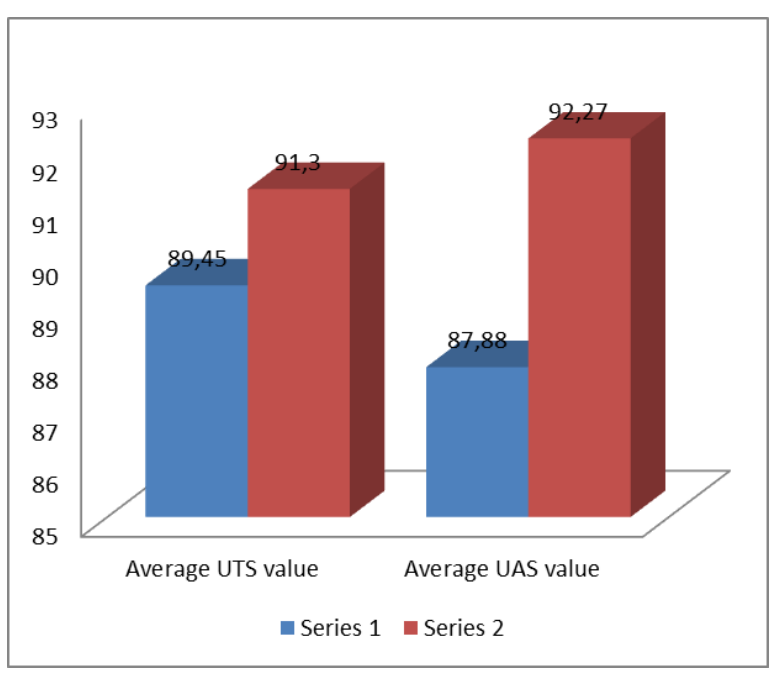

Fig. 1. Students' Average Scores on the Mid-Term (Left) and Final (Right) Tests

\section{Conclusions}

According to the data analysis and discussion, the use of humor in the Educational $\mathrm{Ca}$ reer course effectively generated instructional communication as well as students' attention and readiness to learn. It was exhibited by their enthusiasm and interest in the course. Thus, the learning process became pleasant and not boring, like when the lecturers use lecturing method.

Humor eradicates the psychological barriers that obstruct the learning process, such as shyness, fear, pressured, and so forth. This is in line with the finding of research conducted by (Kurniawan et al., 2018) that a learning media can accelerate students' independence and learning results. That learning nuance is strongly acknowledged by the researcher, as mentioned by (Putro et al., 2017; Smith \& DeCoster, 2000), They said , that teachers in successful classroom management strongly notice psychological and social skills..

In this research, the use of mind mapping was effective improving students' 2st-century skills, in communication among students and lecturers, discussing group collaboration or cooperation students' critical thinking skill in delivering their opinion, and also students' creativity to use multimedia and create learning media (vlog). (Elmunsyah et al., 2019; Tasiam et al., 2017) state that media with a 21st-century approach can improve students' learning motivation and learning interest.

According to our conclusion, teachers and lecturers are expected to conduct pleasant learning processes that do not only focus on lecturing or giving assignments. Besides, the learning materials should also be upgraded to correspond to the current developments by offering the skills required in the 21 st century. With these 2nd-century skills, students are expected to be prepared to face the competition in the globalization era. 


\section{Acknowledgment}

The researcher addresses her gratitude for all people who have contributed to this research.

\section{References}

Adnyana, I. M. D. S., \& PF, K. A. P. D. (2019). Implikasi keterampilan abad 21 pada proses pendidikan agama hindu. Journal of Chemical Information and Modeling, 53(9), 1689-1699. https://doi.org/https://doi.org/10.1017/CBO9781107415324.00 4

Anggraeni, A. D. (2018). Metode role playing dalam pembelajaran profesi kependidikan. Jurnal Pendidikan Progresif, 8(1), 29-35. https://doi.org/https://doi.org/10.23960/jpp .v8.i1.201804

Anggraeni, A. D., \& Pentury, H. J. (2018). Using graphic organizer as a media in students' writing project. Scope: Journal of English Language Teaching, 2(02), 105-111. https://doi.org/https://doi.org/10.30998/ scope.v2i02.2307

Astuti, T, P. (2019). Model problem based learning dengan mind mapping dalam pembelajaran IPA abad 21. Proceeding of Biology Education, 3(1), 64-73. https://doi.org/https://doi.org/10.21009/pbe.3-1.9 .

Elmunsyah, H., Hidayat, W. N., \& Asfani, K. (2019). Interactive learning media innovation: utilization of augmented reality and pop-up book to improve user's learning autonomy. Journal of Physics: Conference Series, 1193(1), 12031.

Gunawan, I. (2013). Metode penelitian kualitatif (Vol. 143). Bumi aksara.

Hidayah, Y. F., Siswandari, S., \& Sudiyanto, S. (2018). Pengembangan media komik digital akuntansi pada materi menyusun laporan rekonsiliasi bank untuk siswa smk. Jurnal Pendidikan Dan Kebudayaan, 2(2), 239-250. https://doi.org/https://doi.org/10.24832/jpnk.v2i2.588

Khsaniatun, N., Sholeh, K., \& Faizah, U. (2014). Implementasi model mind mapping (peta pikiran) dalam pembelajaran menulis teks anekdot pada siswa kelas x Smk Pariwisata Dalung. Jurnal Pendidikan Dan Pembelajaran Bahasa Indonesia, 3(1).
Kurniawan, H. R., Elmunsyah, H., \& Muladi, M. (2018). Perbandingan penerapan model pembelajaran project based learning (PJBL) dan think pair share (TPS) berbantuan modul ajar terhadap kemandirian dan hasil belajar rancang bangun jaringan. JP (Jurnal Pendidikan): Teori Dan Praktik, 3(2), 80-85.

Mariyan, N. W. I., Marhaeni, A. A. I. N., \& Sutama, M. (2013). Pengaruh implementasi strategi mind mapping terhadap prestasi belajar menulis kreatif ditinjau dari kreativitas siswa (Vol. 3, Issue 2, pp. 1-10). Ganesha University of Education.

Muhlisin, A., \& Kunci, K. (2017). Inovasi model pembelajaran RMS untuk meningkatkan kecakapan abad 21. Seminar Nasional Hayati V, 27-36.

Musyafa, M, I. (2017). Hubungan antara efikasi diri dengan kecemasan komunikasi dalam bersiaran pada penyiar radio Kota Malang. Universitas Islam Negeri Maulana Malik Ibrahim.

Putro, S. C., Elmunsyah, H., Putranto, H., \& Nidhom, A. M. (2017). Pengaruh aspek sosial psikologis terhadap kesiapan menjadi guru SMK di jurusan TE FT um. Teknologi Dan Kejuruan: Jurnal Teknologi, Kejuruan, Dan Pengajarannya, 40(1), 59-68.

Setyarini, D. (2019). Metode pembelajaran mind map untuk meningkatkan prestasi belajar anak didik sekolah dasar. Jurnal Ilmiah Pendidikan Dasar, 6(1), 30-44. https://doi.org/DOI: http://dx.doi.org/10.30659/pendas.6.1.30-44

Smith, E. R., \& DeCoster, J. (2000). Dual-process models in social and cognitive psychology: Conceptual integration and links to underlying memory systems. Personality and Social Psychology Review, 4(2), 108131.

Sugiyono, P, D. (2017). Metode penelitian bisnis: Pendekatan kuantitatif, kualitatif, kombinasi, dan $R \& D$. Alfabeta.

Tasiam, F. J., Kustono, D., \& Elmunsyah, H. (2017). The competence readiness of the electrical engineering vocational high school teachers in Manado towards the ASEAN economic community blueprint in 2025. Journal of Education and Learning, 11(3), 337-342. 